\title{
Pengaruh Penggunaan Metode Sugestopedia Dalam Pembelajaran Bahasa Arab Pada Siswa Kelas XII SMA Negeri 1 Jamblang
}

\author{
Fauziya \\ Institut Agama Islam Negeri (IAIN) Syekh Nurjati Cirebon \\ Email: khafa.zahra@gmail.com \\ Hasan Saefuloh \\ Institut Agama Islam Negeri (IAIN) Syekh Nurjati Cirebon \\ Email:hazansf@yahoo.com
}

\section{ملخص}

نتيجة البحث هذه المقالة العلمية عن تعليم مهارة الكلام في فصل المراقبة بدون طريقة الإيهائية (Sugestopedia) هي الاختبار القبلي يكصل على النتيجة السفلى •ـ ونتيجة الأعلى 00. ومن الاختبار البعدي أن النتيجة ونتيجة الأسفل ه v ونتيجة الأعلى .م. والنتيجة قدرة الطلاب على مهارة الكلام باستخدام طريقة الإيحائية (Sugestopedia) الاختباري في فصل التجربة هي الاختبار القبلي أن النتيجة السفلى .ب والنتيجة العليا •. ومن الاختبار البعدي أن النتيجة السفلى •v والنتيجة العليا .q. يكصل على نتيجة

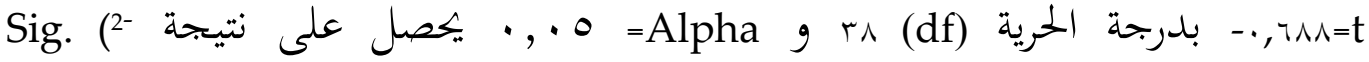
بإئtailed) عن إستخدام الطريقة الإيحائية في الفصل الثاني عشر بالمدرسة الثانوية الحكومية المبل جمبالنج. وأما منهج البحث هذه المقالة هو بحث كمي، بالطريقة التجريبية وأما في أساليب التحليل فأخذها الباحثة إلى تقرير الفرقة (Gain) وبتربة العادية أو اللزوم وبحربة الفروض. وطريقة جمع الحقائق في هذه الرسالة بالمقابلة الشخصية والاختبار القبلي والبعدي. 


\title{
الكلمات الائيسية: طريقة الإيحائية، مهارة الكلام، المدرسة العالية الحكومية \\ الأولى جمبلانج
}

\begin{abstract}
Abstrak
Artikel ini membuktikan pembelajaran keterampilan berbicara di kelas control (kelas XII IPS-3) tanpa menggunakan metode pembelajaran Sugestopedia pada saat pretest yaitu (Minimun) 40 dan (Maximun) 55, post-test menghasilkan nilai (Minimun) 75 dan (Maximun) 80. Serta hasil kemampuan siswa pada maharat al-kalam dengan menggunakan metode pembelajaran Sugestopedia di kelas Eksperimen (kelas XII IPA-5) nilai saat pretest yaitu (Minimun) 60 dan (Maximun) 80. Sedangkan nilai siswa saat post-test yaitu menghasilkan nilai (Minimun) 70 dan (Maximun) 90. Dari hasil yang telah dipaparkan diatas menghasilkan nilai $t=-0,688$ dengan (df) 39-1=38, Alpha $=0,05$ menghasilkan ( tiled $^{-2}$ ). Sig 0,496>0,05 . Berdasarkan data diatas berarti ada pengaruh terhadap penggunaan metode Sugestopedia dalam meningkatkan siswa pada Maharat al-kalam.

Penelitian ini menggunakan metode eksperimen dengan pendekatan kuantitatif, adapun teknik Analisis datanya peneliti menggunakan Gain, uji Normalitas, uji Homogenitas, Hipotesis dan teknik pengumpulan data peneliti menggunakan wawancara, nobservasi, tes dalam bentuk pre-test dan post-test.
\end{abstract}

\section{Kata Kunci: Metode Sugestopedia, Keterampilan Berbicara, SMA Negeri 1 Jamblang}

\section{Pendahuluan}

Keberagaman peserta didik dalam suatu pembelajaran bahasa Arab menjadi perhatian tersendiri bagi seorang guru. Hal tersebut tentunya berhubungan dengan tingkat keberhasilan dalam sebuah pembelajaran. Ahmad Hasan Hawatereh mengatakan bahwa keberhasilan suatu pembelajaran bahasa Arab bergantung atas 3 aspek, yaitu kegiatan pembelajaran, bahasa, dan interaksi sosial. Termasuk dalam aspek kegiatan pembelajaran yaitu guru, siswa, bahan ajar (buku), teknologi dan semua aspek yang mendukung kegiatan pembelajaran itu berlangsung. ${ }^{1}$

${ }^{1}$ Mohd Fadzli Ismail, \& Mohd Sukki Othman, "Faktor-faktor yang mempengaruhi pencapaian pelajar dalam pengajaran \& pembelajaran bahasa Arab: Satu tinjauan di SMAP Kajang", dalam Jurnal Persidangan Kebangsaan Pengajaran Dan Pembelajaran Bahasa Arab 2012 (PKEBAR) Volume 12. Hal. 175. ISBN 9789675478499. Diakses tanggal 2 Maret 2016 Pukul 22.30 WIB. 
Dalam pembelajaran terdapat 4 aspek yang begitu penting yang harus dikuasai oleh peserta didik, diantaranya yaitu keterampilan menyimak (Maharat al-istima'), keterampilan berbicara (Maharat al-kalam), keterampilan membaca (Maharat al-qira'ah) dan keterampilan menulis (Maharat al-kitabah). ${ }^{2}$ Dan di setiap pembelajaran keterampilan tersebut membutuhkan pendekatan, metode, strategi dan media, yang sesuai dengan tujuan pada masing-masing pembelajaran.

Perhatian pihak sekolah pun dalam pembelajaran bahasa Arab sangatlah penting, baik dalam penyediaan sarana dan prasarana serta kesiapan dari seorang guru sebelum melaksanakan kegiatan pembelajaran di kelas. Aspek yang sangat penting adalah dalam pemilihan metode pembelajaran yang akan digunakan untuk menyampaikan materi di dalam kelas. Pemilihan metode ini tentunya harus sesuai dengan tujuan dari pembelajaran itu sendiri. Menurut Nik Muhadi Rahimi (2005), pemilihan metode yang sesuai disetiap pembelajaran (bahasa Arab) dengan tujuan pembelajaran yang digunakan akan sangat membantu peserta didik dalam memahami materi dengan baik serta memudahkan guru dalam materi yang akan disampaikan. ${ }^{3}$

Terdapat beberapa macam metode dalam pembelajaran bahasa Arab, diantaranya: metode kaidah dan tarjamah (The GrammarTranslation Method), metode aural oral (Aidio Lingual Method), metode langsung (The Direct Method), metode diam (The Silent Way), metode gabungan (The Community Language Learning), ${ }^{4}$ dan metode Sugestopedia (The Sugestopedy Method) ${ }^{5}$.

Ada beberapa hal yang harus diperhatikan oleh seorang guru dalam mengajar bahasa Arab, diantaranya adalah adanya upaya yang sangat besar, kreativitas, media pengajaran, serta menggunakan metode

' 'عبدالعزيز العصيلي، طرائق تدريس اللغة العربية للناطقين بلغات أخرى (الرياض: فهرسة مكتبة الملك فهد الوطنية أثناء النشر،

.$I V .0$.

${ }^{3}$ Mastura Arshad \& Kaseh Abu Bakar, "Penggunaan strategi pembelajaran kemahiran bertutur bahasa Arab", dalam Jurnal Persidangan Kebangsaan Pengajaran Dan Pembelajaran Bahasa Arab 2012 (PKEBAR) Volume 12. Hal. 14. ISBN 9789675478499. Diakses tanggal 2 Maret 2016 Pukul 22.30 WIB.

" عبدالعزيز العصيلي، طرائق تدريس اللغة العربية للناطقين بلغات أخرى (الرياض: فهرسة مكتبة الملك فهد الوطنية أثناء النشر،

rr.

${ }^{5}$ Aziz Fahrurrozi \& Erta Mahyudin, Pembelajaran Bahasa Arab. (Jakarta: Direktorat Jendral Pendidikan Islam Kememntrian Agama RI, 2012). Hal. 179. 
dan strategi pembelajaran yang sesuai dengan tujuan pembelajaran tersebut. Semua aspek tersebut membuat kegiatan pembelajaran berlangsung lebih terencana dengan baik.

Metode-metode yang digunakan dalam pembelajaran bahasa Arab begitu beragam, sesuai yang telah dipaparkan diatas, salah satunya yaitu metode sugestopedia yang merupakan metode dengan memanfaatkan sugesti yang terdapat dalam diri setiap manusia. Dalam hal seperti ini menurut Pateda (1991) isyarat-isyarat sugestif dan emosional yang tidak disadari dapat dikoordinasikan sebaik mungkin. Ada enam komponen utama Metode Suggestopedia yang dikembangkan dari sugestologi, yakni (1) kekuasaan atau otoritas guru. (2) siswa dibuat seperti kanakkanak (infantilisasi), (3) sumber belajar ganda, (4) intonasi, (5) irama, dan (6) sikap yang santai. Tujuan umum Metode Suggestopedia adalah mengembangkan kecakapan atau keterampilan berbicara yang lebih baik dan lancar secara cepat. ${ }^{6}$

Berdasarkan observasi penulis di SMA Negeri 1 Jamblang, khususnya di kelas XII baik kelas XII IPA dan atau kelas XII IPS, proses pembelajaran bahasa Arab disana masih menggunakan metode tradisional yang terkesan monoton serta kurangnya ragam media yang digunakan oleh guru menjadikan kegiatan pembelajaran terkesan membosankan. Metode tradisional ini merupakan metode yang lazim dan sudah biasa diterapkan oleh guru dalam pembelajaran. Metode ini menggunakan sistem pembelajaran yang berpusat pada guru dengan cara yang sangat sederhana, yaitu ceramah. ${ }^{7}$ Penggunaan metode ceramah dengan terus menerus mengakibatkan rasa bosan serta motivasi belajar peserta didik dalam mengikuti pembelajaran bahasa Arab menjadi berkurang. Akibatnya, tujuan dan targe pembelajaran bahasa Arab tidak optimal bahkan kurang berhasil.

\section{Metode Penelitian}

Kemudian Metode yang digunakan dalam penelitian ini adalah quasi eksperimen dengan pendekatan kuantitatif untuk mempengaruhi penggunaan metode pembelajaran Sugestopedia untuk meningkatkan

${ }^{6}$ Aziz Fahrurrozi \& Erta Mahyudin, Pembelajaran Bahasa Arab.... Hal. 179-181.

7 Sapri, "Metode Pembelajaran Bahasa Arab: antara Tradisional dan Modern", dalam Jurnal INSANIA. Volume. 13. No. 03. Hal. 03. Edisi Sept-Des 2008. Diakses tanggal 2 Maret 2016 Pukul 22.30 WIB. 
maharat al-kalam pada siswa kelas XII SMA Negeri 1 Jamblang antara kelas eksperimen dan kelas control.

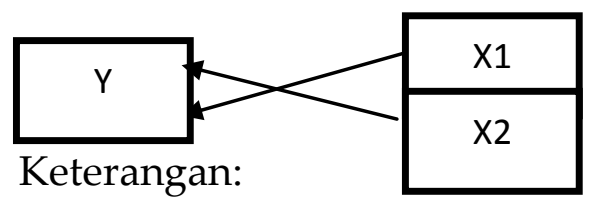

Variabel X1 = Pembelajaran bahasa

Arab dengan menggunakan metode Sugestopedia

Variabel X2 = Pembelajaran bahasa

Arab tanpa menggunakan metode Sugestopedia

Variabel $\mathrm{Y}=$ Pembelajaran bahasa

Arab dalam keterampilan berbicara

$=$ Pengaruh $^{8}$

Dari gambar di atas peneliti mengetahui bahwa variabel $X$ dapat mempengaruhi variabel Y. Mengenai desain penelitian, peneiiti menggunakan Non-equivalent Control Group Design.

Dalam desain ini serupa dengan Pretest-posttest Control Design. Akan tetapi Non-equivalent Group Design, kelompok eksperimen dan controlnya tidak dapat memilih secara acak (random). Adapun Pretestposttest Control Design, kelompok eksperimen dan controlnya dipilih secara random (acak).

Sumber data yang diambil oleh peneliti, (1) siswa kelas XII SMA Negeri 1 Jamblang untuk memperoleh data tentang kemampuan mereka dalam keterampilan berbicara dengan menggunakan bahasa Arab, (2) beberapa buku yang berhubungan dengan penelitian ini. Populasi dalam penelitian ini yaitu seluruh siswa kelas XII SMA Negeri 1 Jamblang dan sample yang digunakan adalah seluruh siswa kelas XII IPA-5 dan kelas XII IPS-3 SMA Negeri 1 Jamblang yang terdiri dari putra dan putri. Teknik pengumpulan data yang digunakan peneliti dalam penelitian ini adalah observasi, wawancara dan tes.

Teknik observasi dilakukan dengan mengamati aktifitas siswa selama pembelajaran yang dilakukan dengan menggunakan metode

${ }^{8}$ Sugiono, Metodologi Penelitian Kualitatif Kuantitatif dan R\&D. (Bandung: Alfabeta, 2011). Hal.112. 
Sugestopedia. Wawancara yang dilaksanakan yaitu wawancara dengan guru dan siswa, wawancara dengan guru mata pelajaran bahasa Arab tentang proses pembelajaran bahasa Arab dan kemampuan siswa terhadap keterampilan berbicara bahasa Arab. Wawancara dengan siswa tentang pendapat mereka yang berhubungan dengan proses pembelajaran bahasa Arab dengan menggunakan metode Sugestopedia. AdapunTes yang dilakukan oleh peneliti adalah berupa pre test dan post test. ${ }^{9}$

Uji Validitas Instrumen memiliki peranan yang sangat penting dalam suatu penelitian, kualitas data sangat mempengaruhi kualitas hasil dari penelitian. Oleh karena itu, untuk mendapatkan hasil penelitian yang baik diperlukan instrumen yang baik pula, dalam hubungan ini instrumen penelitian harus memenuhi kriteria validitas dan reliabilitas agar penggunaanya dalam suatu penelitian dapat menghasilkan data yang akurat dan objektif serta dapat dipertanggungjawabkan.

Peneliti menggunakan rumus Alpha untuk mencari reliabilitas instrumen bentuk uraian sebagai berikut: ${ }^{10}$

Keterangan :

$$
r_{11}=\left(\frac{k}{(k-1)}\right)\left(1-\frac{\sum \sigma b^{2}}{\sigma^{2} t}\right)
$$

$$
\begin{array}{ll}
r_{11} & =\text { reabilitas instrumen } \\
k & =\text { banyaknya soal } \\
\sum_{\sigma^{2} t} \sigma b^{2} & =\text { jumlah variant butir } \\
& =\text { skor pada belahan awal-skor pada belahan } \\
& \text { akhir }
\end{array}
$$

Dalam Penelitian ini, peneliti menggunakan hipotesis komparatif 2 sample, untuk menguji homogenitas sample varians diuji bedasarkan rumus sebagai berikut :

$$
F=\frac{S_{1}^{2}}{S_{2}^{2}}
$$

\footnotetext{
${ }^{9}$ Arikunto \& Suharsimi, Prosedur Penelitian. (Jakarta: PT Rineka Cipta, 1996). Hal. 200.

10 Arikunto \& Suharsimi, Prosedur Penelitian.... Hal. 239.
} 
Keterangan :

$\begin{array}{ll}\mathrm{F} & : \text { Nilai } \mathrm{F} \text { terhitung } \\ S_{1}^{2} & : \text { Nilai varian terbesar } \\ S_{2}^{2}: \text { Nilai varian terkecil }\end{array}$

Pengujiannya menggunakan statistik inferensial parametris dengan rumus t-testindependen (rumus polled varian) untuk menentukan perbedaan rata-rata dari kelas eksperimen dan kelas kontrol:11

$$
t=\frac{\overline{X_{1}}-\overline{X_{2}}}{\sqrt{\frac{\left(n_{1}-1\right) S_{1}^{2}+\left(n_{2}-1\right) S_{2}^{2}}{n_{1}+n_{2}-2}\left(\frac{1}{n_{1}}+\frac{1}{n_{2}}\right)}}
$$

Keterangan :

$\overline{X_{1}} \quad:$ Rata-Rata Sampel 1

$\quad \frac{1}{X_{2}} \quad$ : Rata-Rata Sampel 2

$n_{1} \quad$ : Jumlah Kelompok Eksperimen

$n_{2} \quad$ : Jumlah Kelompok Kontrol

$S_{1}^{2} \quad$ : Varian Sample 1

$S_{2}^{2} \quad$ : Varian Sample 2

Untuk menganalisis data tersebut peneliti menggunakan program SPSS for window 16.

\section{Pembelajaran Bahasa Arab di SMA Negeri 1 Jamblang}

SMA Negeri 1 Jamblang merupakan salah satu SMA Negeri di Kabupaten Cirebon dengan akreditasi A, beralamat di Jalan Nyimas Rorokerta Nomor 33 Desa Sitiwinangun Kecamatan Jamblang Kabupater Cirebon Jawa Barat, dengan kode pos 45156. Di SMA Negeri 1 Jamblang terdapat 2 guru mata pelajaran bahasa Arab, yaitu:

\begin{tabular}{|c|c|l|c|}
\hline No. & Nama Guru & \multicolumn{1}{|c|}{ Lulusan } & Jenjang \\
\hline 1. & $\begin{array}{c}\text { Dra. Agus } \\
\text { Herawati }\end{array}$ & $\begin{array}{l}\text { UNINUS Fakultas } \\
\text { pendidikan Jurusan Bahasa } \\
\text { dan Seni Arab }\end{array}$ & S1 \\
\hline 2. & Drs. Moh. Akhid & $\begin{array}{l}\text { IKIP Bandung Fakultas } \\
\text { Bahasa Jurusan Bahasa } \\
\text { Arab S1 }\end{array}$ & S \\
\hline
\end{tabular}

${ }^{11}$ Sugiono, Metodologi Penelitian Kualitatif Kuantitatif dan R\&D. (Bandung: Alfabeta, 2011). Hal. 264. 
Mata pelajaran bahasa Arab di SMA Negeri 1 Jamblang ada sejak tahun 1995 dengan kedudukannya sebagai mata pelajaran mulok. Selanjutnya keberadaan mata pelajaran bahasa Arab sempat terhenti atau ditiadakan pada tahun 2000, hingga tahun 2008. Pada tahun 2008 di semester ganjil mata pelajaran bahasa Arab diadakan lagi hingga sekarang.

Kegiatan pembelajaran bahasa Arab di SMA Negeri 1 Jamblang masih belum maksimal dalam proses penyampaiannya. Hal tersebut terlihat pada strategi atau metode pembelajaran yang digunakan dalam pembelajaran bahasa Arab terkesan monoton dan membosanan karena guru menggunakan metode pembelajaran konvensional yang bersifat teacher centered, yaitu pembelajaran yang bersumber pada guru. Metode yang seperti itu mengakibatkan peserta didik bersikap pasif saat proses pembelajaran berlangsung.

Sebagaimana hasil wawancara dengan guru bahasa Arab di kelas XII SMA Negeri 1 Jamblang, Drs. Agus Herawati menyatakan bahwa dalam kegiatan pembelajaran bahasa Arab, guru jarang menggunakan media yang membuat peserta didik tertarik untuk mempelajari bahasa Arab dengan antusias, serta metode yang digunakan masih dengan cara lama dan yang terpenting materi tersampaikan.

Penggunaan metode yang tradisional dalam penyampaian materi bahasa Arab, khususnya dalam penyampaian materi mengenai keterampilan berbicara (maharat al-kalam) guru lebih sering menggunakan metode qowaid wa tarjamah, yang mana guru menerangkan dan menerjemahkan teks dialog kemudian menyuruh siswa untuk membacakan teks dialog tersebut. Hal tersebut dapat mengakibatkan peserta didik tidak dapat mengembangkan skillnya dalam keterampilan berbicara Bahasa Arab, dan jelas hal ini membuat mereka bersikap pasif saat kegiatan pembelajaran berlangsung (Hasil Observasi \& wawancara).

\section{Metode Sugestopedia}

Metode sugestopedia merupakan metode pembelajaran bahasa (bahasa asing) yang menggunakan pendekatan komunikatif. ${ }^{12}$ Landasan yang paling dasar pengajaran bahasa Metode Sugestopedia adalah sugestologi, yang menyatakan bahwa manusia bisa diarahkan untuk

12 Hafidah, "Metode Pembelajaran Bahasa Arab Komunikatif", dalam Jurnal Forum Tarbiyah, Volume 10, Nomor 02, Desember 2012. Hal. 212-213. Diakses tanggal 2 Maret 2016 Pukul 22.30 WIB. 
melakukan sesuatu dengan sugesti. Faktor sugesti yang utama adalah: (a) pendekatan yang digunakan guru, (b) kewibawaan, prestise dan wewenang guru yang menerapkan pendekatan itu, (c) kepercayaan dari pihak siswa terhadap pendekatan gurunya, (d) kedwiparasan komunikasi, dan (e) seni (musik). ${ }^{13}$

Effendi (2009) menyatakan bahwa Metode Suggestopedia didasarkan atas asumsi bahwa teknik relaksasi dan konsentrasi akan membantu peserta didik membangkitkan sumber-sumber bawah sadar dan menyimpan sejumlah struktur dan kosa kata yang lebih besar. Maka harus diciptakan atmosfir yang sugestif di kelas. ${ }^{14}$

Menurut Bancropt, bahwa ada enam unsur dasar dari metode Suggestopedia ini, diantaranya: ${ }^{15}$

a. Authority, yaitu adanya otoritas guru atau semacam tsiqqah dari seorang guru, yang membuat peserta didik yakin dan percaya pada dirinya sendiri (self confidence). Dan ketika peserta didik memiliki kepercayaan diri akan merasa aman atau nyaman, maka akan berani untuk berkomunikasi. Kemampuan guru dalam meningkatkan keyakinan dan percaya diri pada peserta didik tentunya bergantung pada sikap yang ditampakan guru tersebut saat pembelajaran berlangsung.

b. Infantilisasi, yaitu peserta didik dibuat seperti kanak-kanak, menerima ilmu dari guru dengan tanpa disadarinya, belajarnya lebih bersifat intuitif serta tidak merasa terbebani dengan belajar secara ilmiah. Belajar seperti anak-anak melepaskan murid dari kungkungan belajar rasional ke arah belajar yang lebih intuitif. Misalnya, penggunaan "role play" dan nyanyian dalam metode ini akan mengurangi rasa tertekan sehingga murid dapat belajar secara alamiah. Ilmu masuk tanpa disadari seperti yang dialami oleh seorang anak kecil yang tanpa sadar menerima ilmu atau pelajaran dietiap aktifitas lesehariannya.

${ }^{13}$ Aziz Fahrurrozi \& Erta Mahyudin, Pembelajaran Bahasa Arab. (Jakarta: Direktorat Jendral Pendidikan Islam Kememntrian Agama RI, 2012). Hal. 180.

14 Hafidah, "Metode Pembelajaran Bahasa Arab Komunikatif", dalam Jurnal Forum Tarbiyah, Volume 10, Nomor 02, Desember 2012. Hal. 202. Diakses tanggal 2 Maret 2016 Pukul 22.30 WIB.

${ }^{15}$ Azhar Arsyad, Bahasa Arab dan Metode Pengajarannya. (Yogyakarta: Pustaka Pelajar, 2003). Hal. 24-25. 
c. Duo-communication, yaitu komunikasi verbal dan nonverbal yang berupa stimulus semangat, baik dari kepribadian seorang guru dan atau dari kondisi kelas, atau berupa rangsangan semangat dari keadaan ruangan dan dari kepribadian seorang guru. Muridmurid duduk di kursi dan memberi semangat. Guru menghindari mimik yang menunjukkan ketidaksabaran, cemberut, sinis, dan kritik-kritik yang negatif. Kemampuan dalam menata dan mengkondisikan kelas oleh guru mempengaruhi berjalannya pembelajaran di kelas.

d. Intonasi, guru menyajikan materi pelajaran dengan intonasi yang berlainan. Dari intonasi mimik yang berbisik dengan suara tenang dan lembut, intonasi yang normal biasa-biasa sampai kepada nada suara keras dramatis.

e. Rhythm, terutama pada pelajaran membaca, maksudnya pelajaran membaca dilakukan dengan irama yang disesuaikan dengan rasa dan pengaturan nafas. Pelajaran membaca dilakukan dengan irama, berhenti sejenak di antara kata-kata dan rasa yang disesuaikan dengan nafas irama dalam. Di sini murid diminta dan diajar untuk menarik nafas selama dua detik, menahannya selama empat detik dan kemudian menghembuskannya selama dua detik. Di sini "yoga" mempunyai pengaruhnya yang sangat besar dalam metode ini. Proses yoga dalam metode sugestopedia tidak hanya untuk pelajaran membaca (maharatul qiro'ah) tapi dalam pelajaran berbicara (maharatul kalam) juga sangat berpengaruh untuk mengatur intonasi dalam berdialog maupun monolog.

f. Keadaan pseuda-passive, peserta didik dalam keadaan rileks karena pada saat-saat rileks seperti itu akan terjadi apa yang disebut hypermnesia di mana daya ingat menjadi kuat.

Tujuan umum Metode Suggestopedia adalah mengembangkan kecakapan atau keterampilan berbicara yang lebih baik dan lancar secara cepat. Lebih spesifik lagi tujuan pengajaran bahasa asing menurut metode ini diantaranya:

a. Membimbing pelajar untuk mencapai kelancaran berbicara dalam tingkat lanjut secara cepat

b. Memberi penguasaan kosakata yang mencapai jumlah yang cukup banyak (kira-kira 80-100 kosakata pada setiap pertemuan kelas) 
c. Menggunakan waktu pelajar secara maksimal dengan penyajian materi sewaktu pelajar sedang terjaga, dan juga sewaktu ia sedang tertidur (sleep-learning). ${ }^{16}$

Penerapan metode sugestopedia melibatkan peserta didik yang secara suka rela mengikuti kelas sugestopedik, tetapi dalam kesukarelaannya itu mereka diharapkan patuh pada peraturan-peraturan kelas dan segala kegiatannya. Sikap mental para siswa selama pelajaran berlangsung, oleh karena itu siswa harus menjauhi segala hal (termasuk makanan dan minuman) yang dapat mengganggu pikiran dan sikap mental mereka. Para pembelajar sama sekali tidak boleh memikirkan, memanipulasi atau menelaah bahan yang disajikan, tetapi harus memelihara serta mempertahankan suatu suasana pseudo-pasif yang merupakan wadah materi tersebut bergerak serta menyusup ke dalam diri mereka.

Peserta didik diharapkan sabar menghadapi hingga mendorong terciptanya sifat kekanak-kanakan (infantilisasi) mereka sendiri. Sebagian hal ini terselesaikan dengan pengakuan akan otoritas sang guru, sementara bagian yang lain dengan mematuhi sepenuhnya segala kegiatan dan segala teknik yang telah dirancang untuk menolong mereka memperoleh kepercayaan pada diri mereka sendiri, spontanitas, dan reseptivitas (daya penerimaan) sang anak. Kegiatan-kegiatan seperti itu mencakup bermain-peran, permainan, nyanyian dan latihan-latihan senam yoga untuk mendapatkan keadaan yang santai dan nyaman selama pembelajaran berlangsung. ${ }^{17}$

Selain peserta didik, peran guru juga tidak kalah pentingnya. Guru merupakan pemilik wibawa/otoritas di dalam kelas. Oleh karena itu, supaya metode ini berhasil, maka para siswa harus mempercayai dan menghargai guru. Para siswa akan memahami informasi secara lebih baik dari seseorang yang mereka percayai selama mereka bersifat lebih responsif terhadap upayanya men-“desugesti» keterbatasan-keterbatasan mereka dan men-"sugesti" betapa mudahnya mereka memperoleh hasil yang diharapkan.

Peran bahan ajar dalam metode sugestopedia sangatlah penting, diantaranya adalah teks-teks yang merupakan garapan para siswa

${ }^{16}$ Aziz Fahrurrozi \& Erta Mahyudin, Pembelajaran Bahasa Arab. (Jakarta: Direktorat Jendral Pendidikan Islam Kememntrian Agama RI, 2012). Hal. 181.

${ }^{17}$ Aziz Fahrurrozi \& Erta Mahyudin, Pembelajaran Bahasa Arab.... Hal. 183 
merupakan teks-teks yang berisi dialog-dialog panjang dalam bahasa sasaran. Didalam teks tersebut terdapat terjemahan dalam bahasa ibu para siswa yang bertujuan untuk memudahkan mereka dalam memahami arti bacaan tersebut. Ada juga beberapa catatan mengenai kosakata dan tata bahasa dalam dialog itu. Bahan ajar yang terdiri dari bahan-bahan penunjang langsung, terutama sekali teks dan rekaman serta bahan-bahan penunjang tidak langsung, seperti peralatan yang biasa ada dalam kelas dan musickeberhasilan dalam penggunaan metode sugestopedia. media-media yang telah disebutkan tersebut ditata dan diatur sedemikian rupa beberapa menit sebelum pembelajaran dengan metode sugestopedia dimulai. Penggunaan media buku atau teks yang digunakan sudah seharusnya mengandung daya emosional dan bersifat menarik serta memikat hati. Masalah-masalah bahasa diperkenalkan sedemikian rupa sehingga tidak mengalihkan perhatian para siswa dari isi pelajaran dan tidak membingungkan mereka. Tema-tema traumatik yang dapat menggoncangkan jiwa dan materi bahasa yang tidak disukai atau yang menimbulkan kebencian dihindarkan dan dijauhi dalam metode ini. Teknik penggunaan metode suggestopedia, antara lain:

a. Penghafalan kosakata dan istilah-istilah dengan kaidah-kaidah tata bahasa yang mendasarinya;

b. Penggunaan dialog-dialog yang realistis dan ulasan-ulasan tentang dialog itu;

c. Penggunaan sketsa-sketsa, dramatisasi-dramatisasi, penceritaan cerita-cerita pendek, deklamasi-deklamasi, nyanyian, dan perjalanan-perjalanan ke lapangan, di mana para pelajar berbicara dalam bahasa target; dan

d. Penggunaan transkripsi fonetik untuk kosakata, perkenalan bentuk-bentuk kata kerja sedini mungkin, dan penggunaan rekaman (tape recorder).

Langkah-langkah penerapan metode sugestopedia seperti yang dilakukan oleh Lozanov di Institute of Suggestology di Sofia, Bulgaria. Kelas tersebut terdiri dari kelompok kecil sekitar 12 siswa selama 4 jam secara intensif setiap hari dalam satu bulan. Setiap jamnya terdiri atas tiga bagian yaitu:

a. Pengulangan (review) dilakukan melalui percakapan, permainan, atau bermain peran. Laboratorium bahasa tidak digunakan dalam bagian ini. Latihan dan koreksi saja yang dapat dilkakukan. 
b. Penyampaian materi beru didasarkan pada situasi yang familiar. Materi ini mencakup dialog panjang sekitar 10 sampai 14 halaman dengan menambahkan penjelasan tata bahasa yang penting dan terjemahan.

c. Seperti yang diungkapkan oleh Amin Rasyid (1997) porsi dari Suggestopedia terbagi dua bagian:

a) Guru membacakan dialog sementara siswa mengikutinya dengan menghirup udara yang dalam (Yoga). Aturannya adalah : Dua detik pertama, menterjemahkan L1 (first language), dua detik ke dua, Frasa bahasa asing dan berhenti sejenak dua detik. Ketika mendengarkan frasa bahasa asing siswa menahan nafas empat menit sambil melihat teks dan mengulang frasa bahasa asing.

b) Aktivitas dari bagian ini adalah guru membaca dengan emosional dan intonasi yang indah. Siswa menutup mata dan melakukan meditasi terhadap teks diringi dengan musik klasik supaya lebih rileks. Untuk mendukung proses belajar tersebut hendaknya disediakan ruangan kelas yang menyenangkan dan menarik dengan pencahayaan dan udara yang memadai. ${ }^{18}$

Metode sugestopedia memiliki kekuatan dan kelemahan dalam proses penerapannya pada pembelajaran bahasa asing. Kekuatan metode sugestopedia diantaranya:

a. Metode ini bisa menumbuhkan kesenangan dalam diri siswa, dengan tokoh khayalan yang diperankan siswa, dengan gaya nonevaluatif sang guru dan dengan materi ajar yang menarik, termasuk penggunaan lagu klasik.

b. Kesinambungan dan panjangnya dialog-dialog yang digunakan efektif membekali siswa dengan dunia khayalan dimana dia dapat berimprovisasi di dalamnya.

c. Jumlah pelajar yang maksimum 12 melahirkan suasana santai seakan-akan pelajar tidak berada dalam kelas.

d. Para siswa bisa memupuk perasaan kerja sama yang kuat antara mereka sendiri karena mereka saling tolong-menolong dalam menyerap semua pelajaran yang diterima.

18 Hafidah, "Metode Pembelajaran Bahasa Arab Komunikatif", dalam Jurnal Forum Tarbiyah, Volume 10, Nomor 02, Desember 2012. Hal. 204-205. Diakses tanggal 2 Maret 2016 Pukul 22.30 WIB. 
Sedangkan kelemahan-kelemahan dari Metode Suggestopedia diantaranya:

a. Hanya dapat digunakan bagi kelompok kecil, dengan jumlah pelajar maksimum 12 orang

b. Dengan sejumlah sarana dan prasarana yang lengkap, sudah tentu sangat mahal biaya penyelenggaraannya

c. Meskipun unik, tetapi penyajian materi yang sebagian besar berdasarkan tata bahasa struktural memberi kesan bahwa metode ini tidak jauh berbeda dengan metode-metode yang lain.

d. Teknik mendengarkan rekaman pada waktu tidur atau sleeplearning belum terbukti dapat menambah keterampilan para pelajar dengan lebih cepat. Ada kemungkinan timbul kelelahan (fatique) dalam jiwa pelajar karena tidak dapat beristirahat dengan tenang.

\section{Pembelajaran Maharatul Kalam Menggunakan Metode Sugestopedia}

Penelitian yang dilakukan oleh peneliti dalam menerapkan metode sugestopedia pada kelas XII SMA Negeri 1 Jamblang di kelas eksperimen yaitu kelas XII IPA-5 dengan tema al-Hiwaayah melalui tahapan sebagai berikut:

a. Sebelumnya kelas di atur sedemikian rupa supaya peserta didik merasa nyaman sesuai situasi kondisi dan jumlah peserta didik dalam kelas tersebut

b. Siswa diperdengarkan alunan musik klasik dan meminta mereka untuk menutup mata, bersamaan dengan itu guru memberikan ilustrasi berupa cerita pendek yang sesuai dengan materi yang akan disampaikan. Kegiatan tersebut bertujuan untuk membuat tenang dan santai pikiran para peserta didik.

c. Setelah mata peserta didik terbuka, guru memberikan stimulus kepada peserta didik mengenai tema pembelajaran yang akaan dibahas pada hari itu.

d. Setelah pemberian stimulus, barulah guru memberikan instruksi untuk melakukan dialog sesuai teks yang terdapat pada guru dengan media poster yang sebelumnya telah disediakan.

e. Kegiatan berdialog dilakukan untuk melihat sejauh mana peserta didik dapat melakukan percakapan bahasa Arab menggunakan teks yang terdapat pada buku. 
f. Selanjutnya guru mengintruksikan peserta didik untuk melakukan dialog mengenai tema "al-Hiwaayah" (hobi) terkait diri masingmasing, tentunya dengan mufrodat yang sederhana dan dapat dipahami peserta didik.

g. Setelah kegiatan dialog, dilanjut pada kegiatan monolog

h. Kegiatan monolog dilakukan dengan menggunakan media poster bergambar, dan meminta peserta didik untuk menceritakan ada yang terdapat pada poster

i. Setelah semua kegiatan diatas dilaksanakan, selanjutnya guru memberikan pertanyaan berkaitan dengan tema, baik itu sesuai teks dalam buku atau mengenai hobi pada masing-masing peserta didik.

\section{Pengaruh Metode Sugestopedia terhadap Keterampilan Berbicara (Maharatul Kalam)}

Penerapan metode sugestopedia pada pembelajaran bahasa Arab khususnya pada keterampilan berbicara (maharatul kalam) di SMA Negeri 1 Jamblang berlangsung dari bulan September hingga bulan November 2017. Penelitian mengenai penerapan metode Sugestopedia tersebut diawali dengan pengambilan data melalui kegiatan pre-test yang dilakukan pada siswa kelas XII IPA-5 (kelas eksperiment) dan siswa kelas XII IPS-3 (kelas kontrol).

Selanjutnya penerapan metode sugestopedia pada pembelajaran bahasa Arab dengan tema al-Hiwaayah pada kelas eksperiment (kelas XII IPA-5). Sedangkan pada kelas kontrol (kelas XII IPS-3) peneliti menerapkan metode langsung dengan tema yang sama. Setelah melalui proses kegiatan pembelajaran dengan metode yang berbeda, peneliti melakukan pos-test pada kedua kelas tersebut. Berdasarkan penelitian tersebut, peneliti mendapatkan hasil sebagai berikut:

a. Setelah dilakukan pre-test dan post-test pada kelas control (kelas XII IPS-3) dengan bentuk test secara dialog dan monolog serta 11 soal dengan waktu 90 menit peneliti mendapatkan hasil seperti bagan dibawah ini 


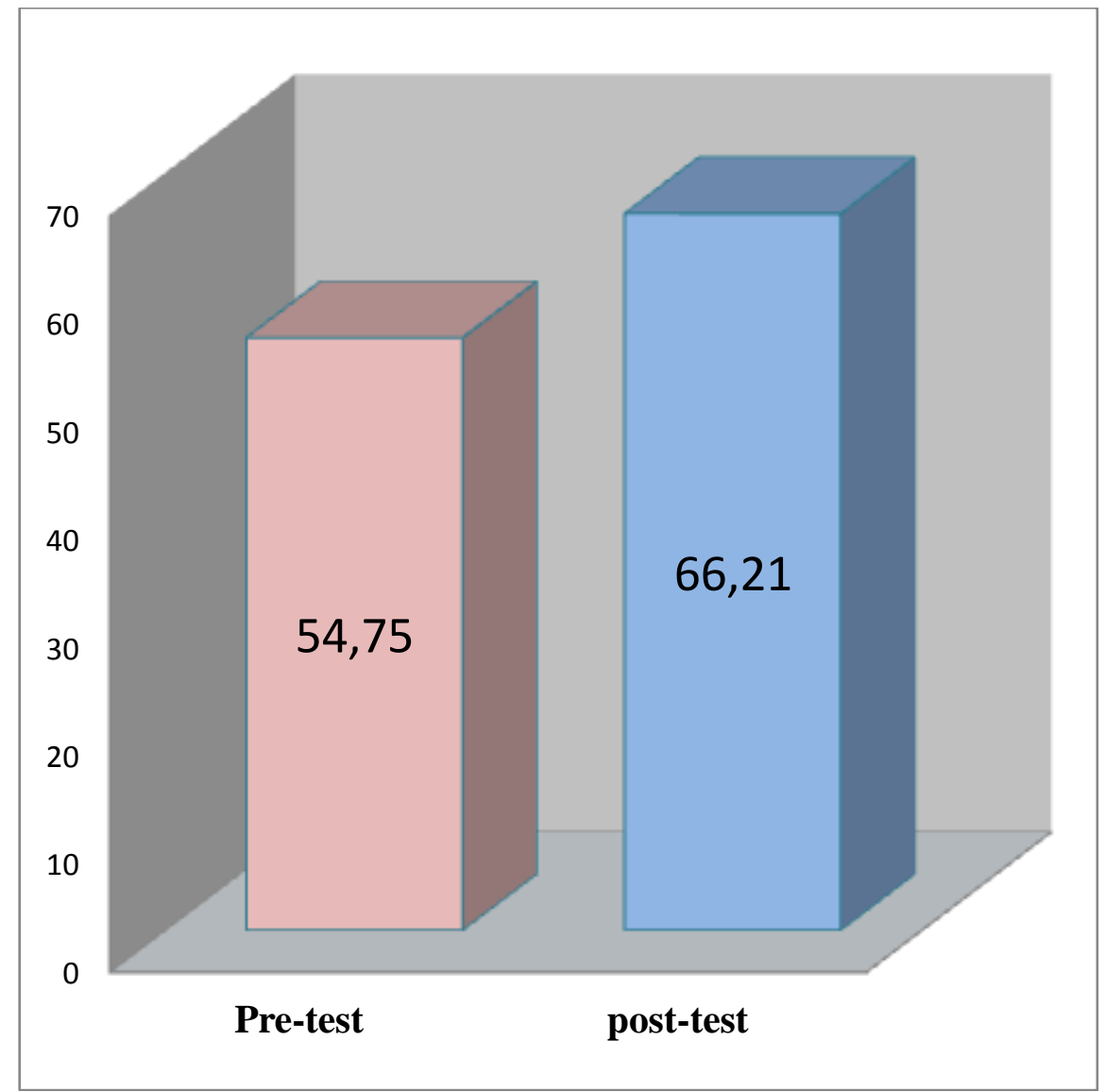

Dari bagan diatas, hasil tes pada kelas kontrol dengan jumlah 41 siswa pada pre-test yaitu mean $=54,75$ median $=55,00$ variance $=77,43$ range $=35$, minimum $=40$, maximum $=75$. Sedangkan hasil dari post-test yaitu mean $=66,21$ median $=65,00$ variance $=49,72$ range $=25$ minimum $=55$ maximum $=80$.

b. Setelah dilakukan pre-test dan post-test pada kelas eksperiment (kelas XII IPA-5) dengan bentuk test secara dialog dan monolog serta 11 soal dengan waktu 90 menit peneliti mendapatkan hasil seperti bagan dibawah ini 


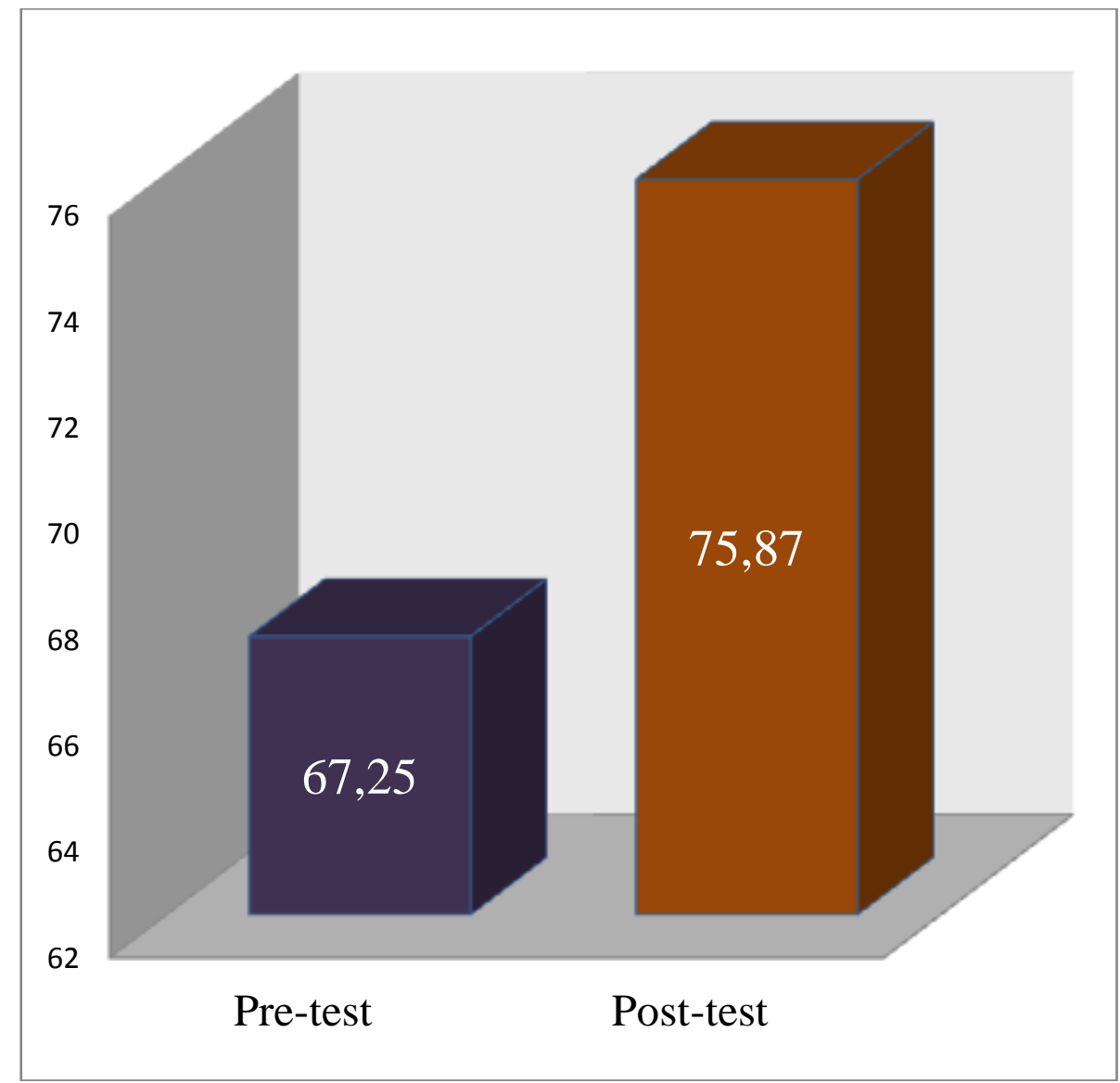

Dari bagan diatas, hasil tes pada kelas eksperimen dengan jumlah 40 siswa pada pre-test yaitu mean $=67,25$ median $=67,22$ variance $=25,57$ range $=20$ minimum $=60$ maximum $=80$. Sedangkan hasil dari post-test yaitu mean $=75,87$ median $=75,57$ variance $=24,21$ range $=20$ minimum $=70$ maximum $=90$.

\section{Kesimpulan}

Kegiatan pembelajaran yang dilakukan di kelas control, tanpa menggunakan metode sugestopedia serta dilakukan post-tes mendapatkan tingkat median 0,23 . Terdapat 1 siswa mendapatkan nilai 80, 5 siswa mendapat nilai 75, 12 siswa mendapatkan nilai 70 dan 23 siswa mendapatkan nilai antara 65-55. Berdasarkan hasil nilai yang dipaparkan sebelumnya, nilai rata-rata dari kelas kontrol adalah 66,34 dengan nilai KKM sebesar 70, hal tersebut menunjukan nilai belajar berada pada tingkat yang rendah.

Kegiatan pembelajaran yang dilakukan di kelas eksperiment dengan menggunakan metode sugestopedia serta dilakukan post-test 
mendapatkan tingkat median 0,27. Terdapat 1 siswa mendapatkan nilai 90, 2 siswa mendapat nilai 85, 11 siswa mendapatkan nilai 80, 15 siswa mendapatkan nilai 75 dan 11 siswa mendapatkan nilai 70. Berdasarkan hasil nilai yang dipaparkan sebelumnya, nilai rata-rata dari kelas eksperimen adalah 75,87 dengan nilai KKM sebesar 70, hal tersebut menunjukan nilai belajar berada pada tingkat yang cukup.

Terdapat pengaruh metode sugestopedia terhadap tingkat pemahaman maharatul kalam siswa kelas XII SMA Negeri 1 Jamblang dengan nilai $t=-0,688$ dengan tingkat $(\mathrm{df})=38$ nilai alpha $=0,05$ menghasilkan (tailed ${ }^{2-}$ ) sig $=0,05<0,496$ dengan nilai maksimum di kelas kontrol sebesar 75 dan nilai maksimum di kelas eksperiment sebesar 80 . Dari kedua rata yang telah dijelaskan pada poin 1 dan 2 dapat disimpulkan bahwa pengaruh penggunaan metode Sugestopedia pada kelas XII di SMA Negeri 1 Jamblang tidak begitu signifikan.

Berdasarkan hasil kesimpulan diatas, maka dapat dilihat bahwa terdapat pengaruh penggunaan metode sugestopedia pada peningkatan kemampuan maharatul kalam pada peserta didik kelas XII di SMA Negeri 1 Jamblang. Akan tetapi, pengaruhnya tidak terlalu signifikan. Hal tersebut dikarenakan oleh beberapa sebab, yaitu diantaranya, motifasi belajar peserta didik dalam mengikuti pembelajaran peserta didik cenderung rendah, hal tersebut dikarenakan sebagian dari mereka menganggap bahwa pembelajaran bahasa Arab itu susah; latar belakang setiap peserta didik yang beragam, seperti karakter belajar, cara belajar hingga intensitas daya serap terhadap materi pembelajaran; selain latar belakang dari peserta didik itu sendiri, adapula sebab dari mereka yang kebanyakan merupakan lulusan dari SMP; sedikitnya waktu yang dialokasikan untuk kegiatan pembelajaran bahasa Arab, yaitu hanya 2 jam pelajaran disetiap minggunya; dan penggunaan metode dan media yang cenderung monoton menjadikan suasana belajar dalam kelas terkesan membosankan. 


\section{Daftar Pustaka}

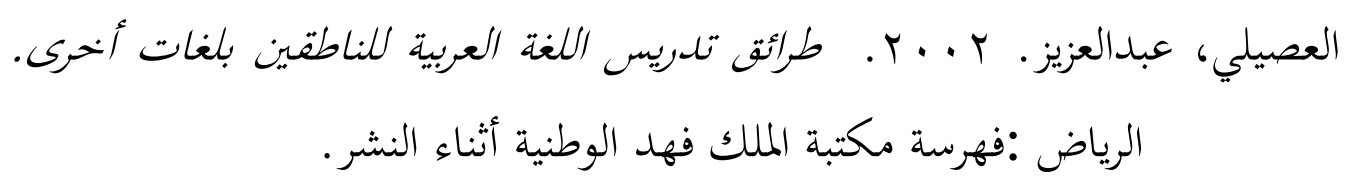

Arikunto. Suharsimi. 1996. Prosedur Penelitian. Jakarta: PT Rineka Cipta.

Arsyad, Azha. 2003. Bahasa Arab dan Metode Pengajarannya. Yogyakarta: Pustaka Pelajar.

Fahrurrozi, Aziz \& Erta Mahyudin. 2012. Pembelajaran Bahasa Arab. Jakarta: Direktorat Jendral Pendidikan Islam Kememntrian Agama RI.

Sugiono. 2011. Metodologi Penelitian Kualitatif Kuantitatif dan RED. Bandung: Alfabeta.

Jurnal Forum Tarbiyah, Volume 10, Nomor 02, Desember 2012.

Jurnal Persidangan Kebangsaan Pengajaran Dan Pembelajaran Bahasa Arab (PKEBAR'12), Volume 12, 2012. Bangi: Unit Bahasa Arab Fakulti Pengajian Islam Universitas Kebangsaan Malaysia.

Jurnal INSANIA, Volume. 13, No. 03, Edisi Sept-Des 2008. 